\title{
Public expenditure and economic growth nexus: Further evidence from Nigeria
}

\author{
Mutiu Abimbola Oyinlola* and Olusijibomi Akinnibosun
}

Department of Economics, University of Ibadan, Ibadan, Nigeria.

Accepted 3 May, 2013

\begin{abstract}
This paper examines the relationship between public expenditure and economic growth in Nigeria during the period 1970-2009. A disaggregated public expenditure level was employed using the Gregory-Hansen structural breaks cointegration technique. The result confirms Wagner's law in two models in the long run; there was a break in 1993 in which the political crisis that engulfed the nation was accountable. The result also shows that economic growth and development are the main objectives of government expenditure, especially investment in infrastructure and human resources all of which falls under social and community services. Based on the result, there should be efforts to maintain adequate levels of investment in social and economic infrastructure.
\end{abstract}

Key words: Public expenditure, economic growth, structural breaks, cointegration.

\section{INTRODUCTION}

The relationship between public expenditure and economic growth has been extensively treated in the theoretical and empirical literature. The theoretical foundation of this relationship can be traced as far back as of the time of Wagner (1883), to Keynes (1936), Peacock and Wiseman (1961), and later to Musgrave (1969). Two schools of thought arose on the direction of causality between public expenditure and economic growth. One is that public expenditure is a consequence of economic growth as posited by Wagner (1883) and the other is by Keynes (1936) who stated that public expenditure is a tool adopted by the government to reverse economic downturns by borrowing money from the private sector and then returning it to them through various spending programmes, hence, economic growth is an outcome of public expenditure.

This relationship is considered empirically in the context of the growing public sector and its impact on economic growth which happened universally almost immediately after the World War II in which two contending views emerged, one is that the decline in economic growth for both developed and less developed countries results from the growth of public sector as posited by Landau $(1983,1986)$ and the other view is that the decline in economic growth for both developed and less developed countries does not result from the growth of public sector as noted in the works of Ram (1986), Singh and Sahni (1984) and Robinson (1977).

Over the past decades, the public sector spending has been increasing in geometric term through government various activities and interactions with its Ministries, Departments and Agencies (MDA's), (Niloy et al., 2003). Although, the general view is that public expenditure either recurrent or capital expenditure, notably on social and economic infrastructure can be growth-enhancing though the financing of such expenditure to provide essential infrastructural facilities-including transport, electricity, telecommunications, water and sanitation, 
waste disposal, education and health-can be growthretarding (for example, the negative effect associated with taxation and excessive debt). The size and structure of public expenditure will determine the pattern and form of growth in output of the economy (Taiwo and Abayomi, 2011).

Empirical works in Nigeria have been concerned with explaining the growth of public expenditure in terms of growth of national income that is testing Wagner's Law (Essien, 1997; Aregbeyen, 2006; Babatunde, 2007; Ighodaro and Oriakhi, 2010). These studies mostly used the cointegration method to determine the long-run relationship between public expenditure and economic growth except for Essien (1997) who used the two step procedure of Engle and Granger (2007) and standard causality test and also Babatunde (2007) who used the bound testing approach. The evidence emerging from these studies mostly showed no support for Wagner's law except Aregbeyen (2006) who confirmed the Wagner's law.

In view of the aformentioned, this paper considers the relationship between public expenditure and economic growth in the context of Wagner's law for the period 1970-2009 and followed Ighodaro and Oriakhi (2010). This paper, however, differs in two ways. First, the components of public expenditure and no aggregates are used and second, the cointegration method adopted allows for structural breaks in data as proposed by Gregory and Hansen (1996).

Adolph (1883), formulated a law referred to as the "Wagner's Law". The law states that there is a persistent tendency both towards an 'extensive' and an 'intensive' increase in the functions of the state. New functions are continually being undertaken and old ones are being performed more efficiently and on an extended scale that increases the spending of the government. Hence, more and more public expenditure is restored for performing these activities. Thus, social progress brought an increase in state activity which in turn meant more government expenditure (Henrekson, 1993). Wagner's law thus states that peoples' demand for services and the willingness to pay is income-elastic hence, the expansion of public economy is influenced by the greater affluence of a nation (Cameron, 1978).

The paper proceeds as follows: reviews on the empirical literature of the subject matter are discussed. Also, the variables used in the paper were described as well as the data sources. Furthermore, the econometric methodology based on cointegration with breaks, elasticity estimates and error-correction (ECM) models are lay out. The empirical findings are presented. Finally, summaries of the major findings and some concluding remarks are discussed.

\section{REVIEW OF EMPIRICAL LITERATURE}

Empirical researches on the effect of government expenditure on economic growth reported results such as: positive effect, negative effect, mixed results and those who could not establish a relationship between government expenditure and economic growth. There were also cross country studies with diverse results as well such as: Positive effect of government consumption on economic growth could be stronger in lower income countries reported by Ram (1986), government expenditures on education and defense have positive influence on economic growth, while expenditure on welfare has insignificant negative impact on economic growth as indicated by Donald and Shuanglin (1993). Abu-Bader and Abu-Qarn (2003) observed bi-directional (feedback) and long run negative relationships between government spending and economic growth while civilian government expenditures have positive effect on economic growth for two out of the three countries they considered.

Similarly, Gregoriou and Ghosh (2007) discovered that countries with large government expenditure tend to experience higher growth, but the effect varies from one country to another. Olugbenga and Owoye (2007) results show the existence of a long-run relationship between government expenditure and economic growth and a unidirectional causality from government expenditure to growth for 16 out of the 30 countries considered, 10 out of the countries confirmed Wagner's law and 4 countries had feedback relationship between government expenditure and economic growth.

Cooray (2009) results revealed that both the size and quality of the government are associated with economic growth. Also, Frimpong and Oteng-Agbaiye (2009) reported that government expenditure does not play a major role in promoting economic growth.

Some authors studied the relationship between the composition of government expenditure and economic growth in the context of Wagner's law and Keynesian notion. Singh and Sahni (1984) as far as expenditures on administration, social and development and defense are concerned upheld both the Wagnerian and Keynesian notion but Keynesian notion alone for debt servicing. Ariyo and Raheem (1991) report that the size and mix of government expenditure as a major determinant of the overall performance of an economy. Ekpo (1994) reported that capital expenditures on transportation and communication, agriculture, health and education had positive impact on economic growth. Ariyo (1996) found that the nature of government expenditure can crowd-in or crowd-out the private sector and Busari (1998) found government capital expenditure to be growth inducing.

A disaggregated approach was adopted by Niloy et al. (2003) to investigate the impact of public expenditure on economic growth for 30 developing countries. They found that government capital expenditure in GDP has a significant positive association with economic growth, but the share of government current expenditure in GDP was shown to be insignificant in explaining economic growth 
while at the sectoral level, government investment and expenditure on education are the only variables that had significant effect on economic growth, especially when budget constraint and omitted variables are included. Devarajan et al. (2006) studied the relationship between the composition of government expenditure and economic growth for a group of developing countries the result show that capital expenditure has a significant negative association with growth of real GDP per capita and recurrent expenditure is positively related to real GDP per capita. Similarly, Maku (2009) investigated the link between government spending on and economic growth in Nigeria by incorporating the model that specifies the effect of government consumption and investment spending, and private investment on real gross domestic product in Nigeria and found that private and public investments have insignificant effect on economic growth during the review period. Ighodaro and Oriakhi (2010) found that increase in total government expenditure as well as specific expenditure on general administration and community and social services that propels economic growth. Adeniyi and Bashir (2011) found that governments spending on agriculture, education, defense and internal security services as well as structural adjustment programme are significant factors that influence economic growth in Nigeria. Usman et al. (2011) investigated the effect of federal government expenditure on economic growth in Nigeria by specifying an augmented Solow model in Cobb-Douglas form with public capital as one of the factors. Results of the regressions show that in the short run public spending has no impact on growth. However, Cointegration and VEC results show that there is long run relationship between public expenditure and growth. Adewara and Oloni (2012) explored the relationship between the composition of public expenditure and economic growth in Nigeria between 1960 and 2008 using the Vector Autoregressive models (VAR). Their findings shows that expenditure on education has failed to enhance economic growth due to the high rate of rent seeking in the country as well as the growing rate of unemployment. They also found that expenditure on health and agriculture contributed positively to growth.

Other studies carried out country specific study since different countries have different levels of economic development. Such studies includes that of Abdullah (2000) in Saudi Arabia, also, Albatel (2002) in Saudi Arabia, Peter (2003) for Sweden, Mitchell (2005) and Liu et al. (2008) for the U.S., Verma and Arora (2010) for India.

Empirical works that examined the relationship between government expenditure and economic growth in Nigeria include: Oyinlola (1993) who reported a posi-tive impact of defense expenditure on economic growth. Fajingbesi and Odusola (1999) observed real government capital expenditure has a significant positive influence on real output and real government recurrent expenditure affects growth only by little. Ogiogio (1995) revealed a long-term relationship between government expenditure and economic growth and also discovered recurrent expenditure exerts more influence than capital expenditure on growth. Akpan (2005) used a disaggregated approach to determine the components and concluded that there was no significant association between most components of government expenditure and economic growth in Nigeria. Nurudeen and Usman (2010) result show that the variables- total capital expenditure, total recurrent expenditure, and government expenditure on education have negative effect on economic growth. While government expenditure on transport and communication, and health, have positive impact on economic growth.

\section{MEASUREMENT AND DATA SOURCES}

Using the functional form that relates the share of public expenditure in GDP with real gross domestic product, this can be written in the log form as:

$$
\ln G X P_{t}=\beta_{0}+\beta_{1} \ln R G D P_{t}+\mu_{t}
$$

Since it is not only economic growth that affects public expenditure, particularly for a developing country like Nigeria, it is necessary to include other control variables. The control variables used in the models follows the models presented by Ighodaro and Oriakhi (2010). The functional form can be re-modeled as:

$$
\ln G X P_{t}=\beta_{0}+\beta_{1} \ln R G D P_{t}+\beta_{2} \ln R E V+\beta_{3} \ln D E B T+\mu_{t}
$$

This paper uses components of public expenditure such as recurrent expenditure, capital expenditure, administrative expenses, community and social service and transfer. As a result five models were arrived at which are as follows:

$$
\begin{aligned}
& \ln R c X P_{t}=\beta_{0}+\beta_{1} \ln R G D P_{t}+\beta_{2} \ln R E V_{t}+\beta_{3} \ln D E B T_{t}+\mu_{t} \\
& \ln C p X P_{t}=\beta_{0}+\beta_{1} \ln R G D P_{t}+\beta_{2} \ln R E V_{t}+\beta_{3} \ln D E B T_{t}+\mu_{t} \\
& \ln A d m X P_{t}=\beta_{0}+\beta_{1} \ln R G D P_{t}+\beta_{2} \ln R E V_{t}+\beta_{3} \ln D E B T_{t}+\mu_{t} \\
& \ln S C X P_{t}=\beta_{0}+\beta_{1} \ln R G D P_{t}+\beta_{2} \ln R E V_{t}+\beta_{3} \ln D E B T_{t}+\mu_{t} \\
& \ln T r X P_{t}=\beta_{0}+\beta_{1} \ln R G D P_{t}+\beta_{2} \ln R E V_{t}+\beta_{3} \ln D E B T_{t}+\mu_{t}
\end{aligned}
$$

where $\operatorname{InR} x X P, \operatorname{InCp} X P, \operatorname{InAdm} X P, \operatorname{In} S C X P$, and $\operatorname{InTr} X P$, are log of expenditure of recurrent, capital, administrative, social and community services, and transfers, 
respectively. While InRGDP, InREV, and InDEBT are log of real GDP, total government revenue, and total debt outstanding (domestic plus external debt), respectively. It is expected that estimates of $\operatorname{InRGDP}$ and InREV are positive and negative for $\operatorname{InDEBT}$. All data used were obtained from the Central Bank of Nigeria Statistical Bulletin (2009).

\section{THE ECONOMETRIC METHODOLOGY}

Gregory and Hansen (1996a) made an important contribution in the existing literature on cointegration by proposing residual-based tests of the null of no cointegration for the listed variables with I(1) order in the presence of structural breaks against the alternative cointegration. The Gregory-Hansen (G-H henceforth) methodology is an extension of the Engle and Granger (1987) cointegration analysis and can be viewed as a multivariate extension of the endogenous break test for univariate series The test allows testing for presence of cointegration among the variables of interest given the variables to be difference stationary or integrated of order one (Singh and Pandey, 2009). G-H proposes three models with different assumptions about structural breaks in the cointegrating relationship. These are, level shift, denoted as $C$; level shift with trend, denoted as $C / T$; and regime shift (both level shift and slope coefficients can change), this can be denoted as $C / S$ (Gregory and Hansen, 1996b). The single break date in these models is assumed to be endogenously determined. Using a two-variable specification, the three models can be stated as follows:

$$
\begin{aligned}
& Y_{t}=\alpha_{1}+\alpha_{2} D_{t k}+\beta_{1} X_{t}+\varepsilon_{t} \\
& Y_{t}=\alpha_{1}+\alpha_{2} D_{t k}+\delta_{t}+\beta_{1} X_{t}+\varepsilon_{t} \\
& Y_{t}=\alpha_{1}+\alpha_{2} D_{t k}+\beta_{1} X_{t}+\beta_{2} X_{t} D_{t k}+\varepsilon_{t}
\end{aligned}
$$

where $Y$ is the dependent variable and $X$ is the independent variable, $t$ is a time trend, parameters $\alpha_{1}$ and $\alpha_{2}$ measure respectively the intercept before the break in $k$ and the shift occurred after the break, $\beta_{1}$ and $\delta$ are slope coefficients attached to the cointegrating vector and time trend respectively, $\beta_{2}$ measures the change in the cointegrating vector after the regime shift, $t$ is a time subscript, $\varepsilon$ is an error term, $\mathrm{k}$ is the break date, and $D_{\mathrm{tk}}$ is a dummy variable defined as

Each of these models therefore permits structural change via the dummy variable Dt which is defined as:

$$
D_{t}= \begin{cases}1 & \text { if } t>K \\ 0 & \text { otherwise }\end{cases}
$$

with $k$ denoting the point at which the break occurs.

This study considers the $\mathrm{GH} 4$ that is the regime shift in the context of models 3 to 7 and see if they conform to Wagner's law. We therefore have models 3 to 7 rewritten as:

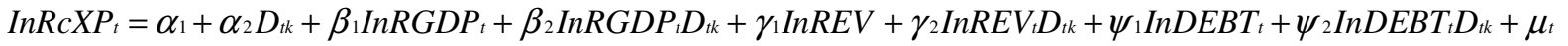

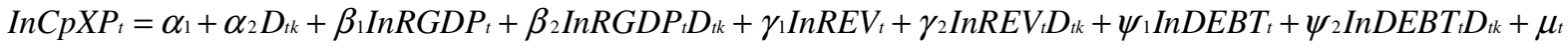

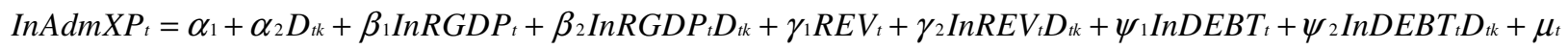

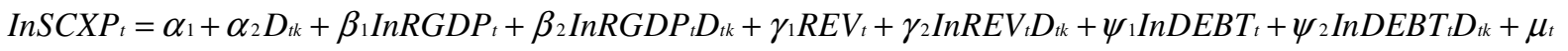

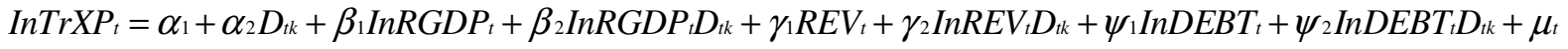

\section{EMPIRICAL RESULT}

\section{Characteristics of the variables}

Table 1 shows the summary statistics for the variables. The skewness values for most of the variables are nearly zero with five having negative signs indicating skewness to the left while the other three with positive signs are skewed to the right. The kurtosis which measures whether the data are peaked or flat relative to a normal distribution with an expected value of 3.0, shows that the real GDP variable satisfies this condition.

Variables are required to have normal distribution before they are used in any parametric statistical method. Skewness and kurtosis give indications as to the nature of distribution of variables. Skewness is a measure of symmetry or the lack of symmetry. The skewness for a normal distribution is zero and any symmetric data should have skewness near zero. The probability value of all variables are high, accepting that the normal distribution for all the variables indicating a normality of their unconditional distributions. The Jarque-bera (JB) test is used to check hypothesis about the fact that a given sample is a sample of normal random variable with unknown mean and dispersion. JB test has the null hypothesis of normal residuals hence; its rejection requires low probability that is the probability that a Jarque-bera statistic exceeds the observed value. The mean to median ratio of each variable is within the unit proximity and standard deviations are on the low side 
Table 1. Descriptive statistics of the variables.

\begin{tabular}{lcccccccc}
\hline Variable & InRcXP & InRGDP & InREV & InDEBT & InCpXP & InAdmXP & InSCXP & InTrXP \\
\hline Mean & 10.49 & 11.81 & 11.39 & 11.89 & 10.16 & 9.55 & 8.77 & 10.20 \\
Median & 10.33 & 12.43 & 11.19 & 12.71 & 9.85 & 9.12 & 8.29 & 10.27 \\
Maximum & 14.57 & 13.48 & 15.88 & 15.65 & 13.96 & 13.94 & 13.09 & 13.63 \\
Minimum & 6.57 & 8.35 & 6.45 & 7.13 & 5.16 & 5.32 & 3.45 & 6.24 \\
Std. dev & 2.56 & 1.51 & 2.80 & 2.97 & 2.49 & 2.65 & 2.72 & 2.37 \\
Skewness & 0.14 & -1.13 & 0.10 & -0.34 & -0.19 & 0.24 & -0.08 & -0.08 \\
Kurtosis & 1.66 & 3.02 & 1.74 & 1.63 & 2.01 & 1.66 & 2.08 & 1.65 \\
Jarque-bera & 3.12 & 8.45 & 2.73 & 3.88 & 1.86 & 3.38 & 1.44 & 3.07 \\
Probability & 0.21 & 0.02 & 0.26 & 0.14 & 0.39 & 0.18 & 0.49 & 0.22 \\
Sum & 419.75 & 472.52 & 455.65 & 475.41 & 406.53 & 382.14 & 350.87 & 407.88 \\
Sum sq. Dev & 254.71 & 88.83 & 306.26 & 343.90 & 241.35 & 273.11 & 288.02 & 218.47 \\
Observations & 40.00 & 40.00 & 40.00 & 40.00 & 40.00 & 40.00 & 40.00 & 40.00 \\
\hline
\end{tabular}

Source: Authors' computation.

Table 2. Unit root test results for Augmented Dickey Fuller.

\begin{tabular}{|c|c|c|c|}
\hline Variable & Level & First difference & Order of integration \\
\hline $\ln A d m X P$ & 0.187 & $8.614^{\star * *}$ & $\mathrm{I}(1)$ \\
\hline $\ln C p X P$ & 1.380 & $6.654^{* * *}$ & $\mathrm{I}(1)$ \\
\hline $\operatorname{InSCXP}$ & 1.017 & $7.130^{\star * *}$ & $\mathrm{I}(1)$ \\
\hline $\operatorname{InRcXP}$ & 0.082 & $7.629^{\star * *}$ & $\mathrm{I}(1)$ \\
\hline $\operatorname{InRGDP}$ & 2.309 & $5.753^{\star * *}$ & $\mathrm{I}(1)$ \\
\hline $\operatorname{InDEBT}$ & 1.512 & $4.265^{\star * *}$ & $\mathrm{I}(1)$ \\
\hline InREV & 1.241 & $6.170^{* * *}$ & $\mathrm{I}(1)$ \\
\hline $\operatorname{In} \operatorname{Tr} X P$ & 1.044 & $8.530^{\star * *}$ & $\mathrm{I}(1)$ \\
\hline
\end{tabular}

Source: Authors' computation; the Mackinnon critical values are $-3.615,-2.941$ and 2.609 at the 1,5 and $10 \%$ levels of significance, respectively. The null hypothesis tests for no unit root $\mathrm{I}(0) .{ }^{*},{ }^{* *},{ }^{* *}{ }^{*}$ indicate significance at the 1,5 and $10 \%$, respectively.

showing small variability.

\section{Results of unit root and cointegration test}

It is important to check for the unit root properties of the individual series being time series in nature in order to avoid the problem of spurious regression. We examined the order of integration of the individual series using the Augmented Dickey-Fuller (ADF) and Phillips Perron (PP) tests of unit root with their results reported in Tables 2 and 3. The ADF and PP tests indicate presence of unit root at level but all the series are stationary at first difference.

\section{Gregory and Hansen cointegration result}

The results of the GH test are presented in Table 4. The result indicates that when there is a regime shift, models $12,13,14$ and 15 are cointegrated as they do not fail to reject the null of no cointegration. However, model 11 fails to reject the null of no cointegration, thus, it is not cointegrated. The break dates of the cointegrated models are 1996, 1996, 1993 and 1990 for models 12, 13, 14 and 15, respectively. The decade of 1990 especially before mid 1990, can be described as a period of policy reversals and lost opportunities. The package of economic reforms embarked upon from the mid-1980s had its backlash effects on the real economy. The experimentation with deregulation and liberalization was truncated in 1994 following the prolonged political crisis that chronicled into a palace coup led by the late Nigeria's Head of State, Gen. Sanni Abacha.

\section{Long run elasticity estimates}

With the inclusion of other variables, the possibility of Wagner's law was verified from only two models: Models 12 and 14. Real GDP is significant and correctly signed in these two models. Table 5 specifically, a percentage 
Table 3. Unit root test results for Phillips Perron.

\begin{tabular}{|c|c|c|c|}
\hline Variable & Level & First difference & Order of integration \\
\hline $\ln A d m X P$ & 0.164 & $8.614^{* \star *}$ & $\mathrm{I}(1)$ \\
\hline $\operatorname{InCpXP}$ & 1.372 & $6.661^{\star \star *}$ & $\mathrm{I}(1)$ \\
\hline $\operatorname{InSCXP}$ & 0.962 & $7.159^{* * *}$ & $\mathrm{I}(1)$ \\
\hline $\operatorname{InR} C X P$ & 0.058 & $8.082^{* \star *}$ & $\mathrm{I}(1)$ \\
\hline InRGDP & 1.820 & $7.092^{\star * \star}$ & $\mathrm{I}(1)$ \\
\hline InDEBT & 1.403 & $4.262^{\star \star *}$ & $\mathrm{I}(1)$ \\
\hline InREV & 1.241 & $6.688^{* * *}$ & $\mathrm{I}(1)$ \\
\hline $\operatorname{InTrXP}$ & 0.974 & $10.81^{\star \star \star}$ & $\mathrm{I}(1)$ \\
\hline
\end{tabular}

Source: Authors' computation; the critical values are $-3.615,-2.941$ and 2.609 at the 1,5 and $10 \%$ levels of significance, respectively. The null hypothesis tests for no unit root $\mathrm{I}(0) .{ }^{*},{ }^{* *},{ }^{* *}{ }^{*}$ indicate significance at the 1,5 and $10 \%$, respectively.

Table 4. Gregory and Hansen test result.

\begin{tabular}{cccccc}
\hline GH model & Model & Estimated breakdate & GH test & $\mathbf{0 . 0 5}$ critical value & Reject $\mathbf{H}_{\mathbf{0}}$ of no cointegration \\
\hline GH4 & 11 & 1997 & -5.589 & -6.00 & NO \\
GH4 & 12 & 1996 & -8.575 & -6.00 & YES \\
GH4 & 13 & 1996 & -6.037 & -6.00 & YES \\
GH4 & 14 & 1993 & -7.961 & -6.00 & YES \\
GH4 & 15 & 1990 & -7.636 & -6.00 & YES \\
\hline
\end{tabular}

$\mathrm{GH} 4$ is Gregory Hansen test with regime shift.

change in real GDP will result in about 0.28 and $0.34 \%$ increase in capital expenditure and Social and community services, respectively. In addition, a percentage change in total revenue will result in about $0.83 \%$ increase in capital expenditure, while same percentage change has a greater impact of $1.07 \%$ increase in social and community services expenditure. An increase in debt however would lead to decreased expenditure in social and community services. The result of model 14 is similar to that of Ighodaro and Oriakhi (2010). Wagner's law cannot be confirmed from the results of other models (Models 11, 13 and 15). Real GDP is only significant in model 13, albeit, with negative sign, while the other two models show that real GDP is not significant. Total revenue plays a significant role in the expenditure patterns of recurrent administrative and transport expenditure in model 14, all the independent variables met a priori expectation. The residuals of models 12, 13, 14 and 15 are thereafter obtained to conduct the short term error correction model.

\section{The error correction modeling}

The short run ECM model is developed by using the LSEHendry general to specific (GETS) framework. The results of short run relationship are presented in Table 6. Just as the long-run case, Wagner's law is confirmed only for capital expenditure in the short-run. The results suggest that Wagner's Law may not be a short run phenomenon as the majority of the models failed to confirm Wagner's law.

Apparently, changes in the respective disaggregated expenditure are found to be associated with revenue in the current period of three of the four models (Models 12, 13 , and 14); while, in addition, with the immediate past period in model 12. In specific terms, the coefficient of total revenue ranges from 0.42 to 0.58 . This implies that a percent increase in revenue in the current period raises disaggregated expenditure by about $0.5 \%$. The results also suggest that an increase in debt obligations raises expenditure on capital and administration in the current period. However, the capital expenditure would decline by about $0.76 \%$ with a similar increase in debt obligation in the immediate past period.

This outcome showed by real GDP in models 12,13 , 14 and 15 could be as a result of non diversification of the Nigerian economy as the nation has a potential of improving on its productive output. To check for the speed of adjustment of the model from the short run to the long run equilibrium state we consider the error correcting term $\left(\mathrm{ECM}_{\mathrm{t}-1}\right)$. The greater the coefficient of the error correcting term, the faster the speed of adjustment of the model from the short run to the long run. The lagged error correction term $\left(\mathrm{ECM}_{\mathrm{t}-1}\right)$ has the expected negative sign implying negative feedback mechanism in 
Table 5. Elasticity estimates for models 11-15.

\begin{tabular}{clccccc}
\hline Model & Dependent variable & Constant & InRGDP & InREV & InDEBT & $\mathbf{R}^{2}$ \\
\hline 11 & $\ln R c X P$ & $0.64(1.35)$ & $-0.08(1.19)$ & $0.77^{*}(15.31)$ & $0.17(2.90)$ & 0.98 \\
12 & $\ln C p X P$ & $-1.57(-1.87)$ & $0.28^{*}(2.31)$ & $0.83^{*}(9.27)$ & $-0.08(-0.80)$ & 0.96 \\
13 & $\operatorname{In} A d m X P$ & $0.30(0.50)$ & $-0.22^{*}(-2.50)$ & $0.95^{*}(14.87)$ & $0.08(1.05)$ & 0.98 \\
14 & $\ln S C X P$ & $-4.24^{*}(-4.76)$ & $0.34^{*}(2.70)$ & $1.07^{*}(11.28)$ & $-0.27^{*}(-2.44)$ & 0.96 \\
15 & $\operatorname{InTr} X P$ & $-0.02(-0.05)$ & $0.09(1.52)$ & $0.54^{*}(12.06)$ & $0.25^{*}(4.74)$ & 0.99 \\
\hline
\end{tabular}

Authors' computation; Figures in parentheses are t-statistic and * shows significance at the $5 \%$ level.

Table 6. Short run error correction models.

\begin{tabular}{|c|c|c|c|c|}
\hline \multirow{2}{*}{ Variable } & Model 12 & Model 13 & Model 14 & Model 15 \\
\hline & $\triangle I n C p X P$ & $\triangle \operatorname{InAdmXP}$ & $\Delta I n S C X P$ & $\Delta \ln T r X P$ \\
\hline Constant & $-0.047(0.47)$ & $0.012(0.11)$ & $-0.069(0.42)$ & $0.021(0.07)$ \\
\hline$\Delta / n C p X P_{t-1}$ & $-0.106(0.67)$ & - & - & . \\
\hline$\Delta \ln C p X P_{t-2}$ & $0.091(0.71)$ & - & - & - \\
\hline$\Delta \operatorname{InAdm} X P_{t-1}$ & - & $-0.106(0.67)$ & - & - \\
\hline$\Delta \operatorname{InAdm} X P_{t-2}$ & - & $0.091(0.71)$ & - & - \\
\hline$\Delta \operatorname{lnSCXP_{t-1}}$ & - & - & $0.228(1.12)$ & - \\
\hline$\Delta I n S C X P_{t-2}$ & - & - & $0.114(0.71)$ & - \\
\hline$\Delta / n T r X P_{t-1}$ & - & - & - & $0.094(0.12)$ \\
\hline$\Delta \ln T r X P_{t-2}$ & - & - & - & $0.251(0.09)$ \\
\hline$\Delta / n R G D P_{t}$ & $0.133(1.93)^{\star *}$ & $-0.277(1.88)^{* *}$ & $0.250(1.06)$ & $-0.063(0.10)$ \\
\hline$\Delta \ln R E V_{t}$ & $0.419(2.99)^{\star}$ & $0.454(2.80)^{*}$ & $0.580(2.40)^{*}$ & $0.399(0.09)$ \\
\hline$\Delta I n R E V_{t-1}$ & $0.702(3.57)^{\star}$ & $-0.019(0.08)$ & $0.182(0.516)$ & $0.177(0.12)$ \\
\hline$\Delta I n R E V_{t-2}$ & $-0.054(0.31)$ & $-0.295(1.46)$ & $-0.272(0.930)$ & $-0.224(0.12)$ \\
\hline$\Delta I n D E B T_{t}$ & $0.482(2.33)^{\star}$ & $0.563(2.63)^{*}$ & $0.182(0.529)$ & $0.403(0.14)$ \\
\hline$\Delta / n D E B T_{t-1}$ & $-0.765(3.39)^{\star}$ & $-0.304(1.31)$ & $0.248(0.64)$ & $-0.378(0.14)$ \\
\hline $\mathrm{ECM}_{\mathrm{t}-1}$ & $-0.212(1.54)$ & $-1.017(3.44)^{\star \star}$ & $-0.954(3.88)^{*}$ & $-0.882(0.18)$ \\
\hline $\bar{R}^{2}$ & 0.43 & 0.38 & 0.39 & 0.59 \\
\hline SER & 0.279 & 0.287 & 0.46 & 0.19 \\
\hline $\mathrm{AIC}$ & 0.507 & 0.564 & 1.509 & -0.277 \\
\hline SIC & 0.943 & 0.999 & 1.944 & 0.159 \\
\hline
\end{tabular}

Note: The absolute t- ratios are in the parentheses below the coefficients * and ** indicate significance at the $5 \%$ and $10 \%$ level, respectively.

the four models i.e. models $12,13,14$ and 15 but it is significant at $10 \%$ in model 13 and $5 \%$ in models 14 and 15. If the ECM coefficient is less than unity, there is a smooth adjustment towards equilibrium; otherwise, the model will not adjust smoothly towards equilibrium. Models 12, 14 and 15 adjust smoothly towards equilibrium with coefficients of $-0.21,-0.95$ and -0.88 respectively. Thus if there are departures from equilibrium in the period, the departure is reduced by about 21 , 95 and $88 \%$, respectively for models 12,14 and 15 . However model 13 will deviate from equilibrium at more than $100 \%$.

\section{CONCLUDING REMARKS}

This study covers five questions which are:
1. Does economic growth translate to growth in recurrent expenditure?

2. Does economic growth translate to growth in capital expenditure?

3. Does economic growth translate to growth in administrative expenses?

4. Does economic growth translate to growth in social and community service?

5. And does economic growth translate to growth in transfer expenditure?

The long run elasticity results showed that economic growth does not translate to growth in recurrent expenditure, administrative expenses and transfer expenditures. In contrast, economic growth leads to growth in capital expenditure as well as in Social and community 
service. It is evident that Wagner's law was also validated in two out of the five models.

These findings can be explained by Wagner's law which indicates that increased government activity and the corresponding increase in government expenditure is an inevitable result of economic growth. In other words, increased friction in society causing greater demand for government services, as the society is growing richer, requires the government to provide quality goods and services and the demand for such goods and services is highly income elastic. This indicates that changes in national income can cause changes in government expenditures as government size in Nigeria has increased both in absolute and relative terms. However, the presence of a cointegrating relationship between the variables in the system suggests that a long term relationship exists between them.

The result show that since economic growth and development are the main objectives of government expenditure, especially investment in infrastructure and human resources all of which falls under social and community services, there should be efforts to maintain adequate levels of investment in social and economic infrastructure.

\section{REFERENCES}

Abdullah HA (2000). The relationship between government expenditure and economic growth in Saudi Arabia. J. Adm. Sci. 12 (2):173-191.

Abu-Bader S, Abu-Qarn AS (2003). Government expenditures, military spending and economic growth: causality evidence from Egypt, Israel, and Syria. J. Policy Model. 25(6-7):567-583. [http://www. sciencedirect.com/science/journal/01618938]

Adeniyi OM, Bashir AO (2011) Sectoral analysis of the impact of public investment on economic growth in Nigeria (1970-2008). Eur. J. Soc. Sci. 20(2):259.

Adewara SO, Oloni EF (2012). Composition of public expenditure and economic growth in Nigeria. J. Emerging Trends Econ. Manag. Sci. 3(4):403-407.

Akpan NI (2005). Government expenditure and economic growth in Nigeria: A disaggregated approach. CBN Econ. Financ. Rev. 43(1):51-69

Albatel AH (2002). Wagner's law and the expanding public sector in Saudi Arabia. J. King Saud University, Adm. Sci. 14 (2):139-156 Riyadh.

Aregbeyen $O$ (2006). Cointegration, causality and Wagner's law: a test for Nigeria. CBN Econ. Financ. Rev. 44 (2):1-7

Ariyo A, Raheem Ml (1991). Effect of fiscal deficit in some macroeconomic aggregates in Nigeria. Final Report to the African Economic Research Consortium, Nairobi, Kenya.

Ariyo A (1996). Economic reform, fiscal stance and the Nigerian private sector, In: Ariyo A (ed) Economic Reform and Macroeconomic Management in Nigeria, Ibadan; Ibadan University Press.

Babatunde MA (2007). A bound testing analysis of Wagner's law in Nigeria: 1970-2006. Appl. Econ. pp.1-8.

Busari TD (1998). Public sector and economic development, 19801994, in Ariyo A. (ed) Public Sector- Private Sector and Economic Development, Ibadan, centre for public-private cooperation.

Cameron DR (1978). 'The expansion of the public economy: a comparative analysis', Am. Polit. Sci. Rev. 72(4):1243-1261.

Cooray A (2009). Government expenditure, governance and economic growth. Comp. Econ. Stud. 51(3): 401-418.

Devarajan S, Swaroop V, Zou H (2006). The composition of public expenditure and economic growth. J. Monetary Econ. 37:313-344.
Donald NB, Shuanglin L (1993). The differential effects of economic growth of government expenditures on education, welfare and defence. J. Econ. Dev. 18(1):1

Ekpo AH (1994). Public expenditure and economic growth in Nigeria, 1960-1992. Final Report African Research Consortium (AERC), Nairobi, Kenya.

Engle RF, Granger CW (1987). "Co-integration and Error Correction: Representation, estimation and Testing", Econometrica 55:251-276.

Essien EA (1997). Public sector growth, an econometric test of Wagner's law. Central Bank of Nigeria. Econ. Financ. Rev. 35:3

Fajingbesi AA, Odusola AF (1999). Public expenditure and growth. A Paper presented at a Training Programme on Fiscal Policy Planning Management in Nigeria, Organized by NCEMA, Ibadan, Oyo State. pp.137-179.

Frimpong JM, Oteng-Agbayie EF (2009). Does the Wagner's hypothesis matter in developing economies? Evidence from three West African Monetary Zone (WAMZ) Countries. Am. J. Econ. Bus. Admin. 1(2):141-147. ISSN 1945-5488.

Gregoriou A, Ghosh S (2007). The impact of government expenditure on growth: empirical evidence from heterogenous panel. [http://www.brunel.ac.uk/9379/efwps/0701.pdf]

Gregory AW, Hansen BE (1996). Residual-based tests for cointegration in models with regime shifts. J. Econom. 70:99-126.

Gregory AW, Hansen BE (1996a). "Residual-based tests for cointegration inmodels with regime shifts," J. Econom. 70:99-126.

Gregory AW, Hansen BE (1996b). "Tests for cointegration in models with regime and trend shifts," Oxf. Bull. Econ. Stat. 58:555-559.

Henrekson M (1993). Wagner's law: a spurious relationship? Public Financ. 48(2): 406-415.

Ighodaro CAU, Oriakhi DE (2010). Does the relationship between government expenditure and economic growth follow Wagner's law in Nigeria? Annals of the University of Petrosani, Economics 10(2):185198.

Keynes JM (1936). The general theory of employment, interest and money. New York: Harcourt, Brace and co.

Landau D (1983). Government expenditure and economic growth: a cross-country study. South. Econ. J. 49:783-792.

Landau D (1986). Government expenditure and growth in less developed countries: an empirical study for 1960-1980. Econ. Dev. Cult. Change. 35: 35-75.

Liu Chih-HL, Hsu C, Younis M (2008). The association between government expenditure and economic growth: the Granger causality test of the U.S. data, 1974-2002. J. Public Budgeting Account. Financ. Manage. 20(4): 439-452.

Maku OE (2009). Does government spending spur economic growth in Nigeria? MPRA Paper No. 17941.

Mitchell JD (2005). The impact of government spending on economic growth. Backgrounder,1831. [www.heritage.org/research/ budget/bg1831.cfm]

Musgrave RA (1969). Fiscal systems. New Haven and London: Yale University Press.

Niloy B, Emranul HM, Osborn DR (2003). Public expenditure and economic growth: a disaggregated analysis for developing countries. [www.socialsciences.manchester.ac.uk/cgber/dpcgbr.30.pdf]

Nurudeen A, Usman A (2010). Government expenditure and economic growth in Nigeria, 1970-2008: a disaggregated analysis. Bus. Econ. J. 4: 1-11.

Ogiogio GO (1995). Government expenditure and economic growth in Nigeria. J. Econ. Manag. 2(1):1

Olugbenga AO, Owoye $O$ (2007). Public expenditure and economic growth: new evidence from OECD countries [http://wwwiaes. confex.com/iaes/Rome_67/techprogram/S1888.HTM]

Oyinlola O (1993). Nigeria's national defense and economic development: an impact analysis. Scand. J. Dev. Alternatives, 12(3):241-253

Peacock AT, Wiseman J (1961). The growth of public expenditure in the United Kingdom. Princeton: Princeton University Press.

Peter S (2003). Government expenditures effect on economic growth: the case of Sweden, 1960-2001. A Bachelor Thesis Submitted to the Department of Business Administration and Social Sciences, Lulea University of Technology, Sweden. 
Ram R (1986) Government size and economic growth: a new framework and some evidence from cross-section and time series data. Am. Econ. Rev. 76: 191-203.

Robinson R (1977). Dependency, government revenue and economic growth, 1955-70. Stud. Comp. Int. Dev.12: 3-28.

Singh P, Pandey MK (2009). Structural Break, Stability and Demand for Money in India. ASRC Working Paper 2009/07.

Singh B, Shani BS (1984). Causality between public expenditure and national income. Rev. Econ. Stat. Vol. 66(4): 630-644.

Taiwo M, Abayomi T (2011). Government expenditure and economic development: Empirical evidence from Nigeria. Eur. J. Bus. Manage. $3(9): 18-28$
Usman A, Mobolaji HI, Kilishi AA, Yaru MA, Yakubu TA (2011). Public Expenditure and economic growth in Nigeria. Asian Econ. Financ. Rev. 1(3): 104-113.

Verma S, Arora R (2010). Does the Indian economy supports Wagner's law? An econometric analysis. Eur. J. Bus. Econ. 3(5):77-91.

Wagner A (1883). Three extracts on public finance, in Musgrave R.A. and Peacock A.T. (eds) (1958), Classics in the Theory of Public Finance. London: Macmillan. 